\title{
Tes dan Pengukuran Kondisi Fisik dan Keterampilan Atlet Bola Tangan Kota Palembang
}

\author{
Arif Hidayat $^{1}$, Bayu Hardiyono ${ }^{2}$, M. Haris Satria ${ }^{3}$ Riyan Pratama $^{4}$ \\ Pendidikan Olahraga, Universitas Bina Darma ${ }^{1,2,3}$ \\ Email.Arif.hidayat@binadarma.ac.id, bayu.hardiyono@binadarma.ac.id, \\ haris@binadarma.ac.id, riyan_pratama@binadarma.ac.id
}

\begin{abstract}
ABSTRAK
Kesegaran jasmani seseorang adalah kemampuan tubuh seseorang untuk melakukan tugas pekerjaan seharihari tanpa menimbulkan kelelahan yang berarti, untuk dapat mencapai kondisi kesegaran jasmani yang prima seseorang perlu melakukan latihan fisik yang melibatkan beberapa komponen kesegaran jasmani dengan metode latihan yang benar. Semakin tinggi tingkat kesegaran jasmani seseorang, semakin besar kemampuan fisiknya dan produktifitas kerjanya, khususnya dalam bidang olahraga. Sebagai Pelatih dan Guru olahraga, yang bertanggung jawab atas prestasi anak asuhannya. Perlu melengkapi dirinya dengan pengetahuan tentang cara-cara mengukur dan menilai status kondisi fisik tersebut.Cara evaluasi yang tepat yang harus dilakukan yaitu dengan cara Tes dan Pengukuran terhadap atlet ataupun siswa. Tes dan pengukuran dapat dilakukan dengan beberapa cara dan tahap yang mempunyai manfaat dan tujan dilakukannya tes tersebut. Dan tes tersebut dibagi menjadi bebrapa komponen kondisi fisik serta beberapa jenis tes yang sudah dikelompokan. Dengan melakukan tes dan pengukuran ini kita dapat mengambil beberapa manfaat, diantaranya kita dapat mengevaluasi tahap latihan yang telah dilakukan, dengan hal itu kita dapat mengetahui seberapa perkembangan kondisi fisik seseorang, selain kita bisa mengembangkan prestasi atlet, kita juga bisa menjadikan ini sebagai bahan perbaikan dalam pemebelajaran atau pelatihan.
\end{abstract}

Kata kunci : Fisik, Olahraga, Pengukuran.

\begin{abstract}
One's physical fitness is the ability of one's body to carry out daily work tasks without causing significant fatigue, to be able to achieve a state of prime physical fitness one needs to do physical exercise that involves several components of physical fitness with the correct training method. The higher the level of a person's physical fitness, the greater his physical ability and work productivity, especially in the field of sports. As a sports coach and teacher, who is responsible for the achievements of his children. Need to equip himself with knowledge of ways to measure and assess the status of the physical condition. The right way of evaluation that must be done is by way of Tests and Measurements on athletes or students. Tests and measurements can be carried out in several ways and stages that have the benefit and purpose of doing the test. And the test is divided into several components of physical condition and several types of tests that have been grouped. By doing these tests and measurements we can take several benefits, including we can evaluate the stages of training that have been carried out, with that we can find out how much progress a person's physical condition is, in addition to being able to develop athlete achievement, we can also use this as material for improvement in learning or training
\end{abstract}

Keywords: Physical, Sports, Measurement. 


\section{PENDAHULUAN}

Pada kehidupan manusia pasti akan dihadapkan dengan beberapa masalah yang ada, sangat kompleks sekali masalah demi masalah yang muncul. Dengan segenap kemampuan yang dimiliki manusia, manusia akan selalu berusaha untuk menyelesaikan semua masalah-masalah itu. Tetapi terkadang seseorang akan lupa terhadap apa yang terjadi pada dirinya sendiri, lebih-lebih pada masalah fisik, yaitu tentang kesegaran jasmani. Banyak dari mereka yang sibuk, akan lupa terhadap kesehatan dan kestabilan kesegaran jasmaninya. Kesegaran jasmani seseorang adalah kemampuan tubuh seseorang untuk melakukan tugas pekerjaan sehari-hari tanpa menimbulkan kelelahan yang berarti, untuk dapat mencapai kondisi kesegaran jasmani yang prima seseorang perlu melakukan latihan fisik yang melibatkan beberapa komponen kesegaran jasmani dengan metode latihan yang benar.

Semakin tinggi tingkat kesegaran jasmani seseorang, semakin besar kemampuan fisiknya dan produktifitas kerjanya, khususnya dalam bidang olahraga. Bagi guru pendidikan jasmani ataupun pelatih, sangat penting mengadakan pelatihan-pelatihan untuk meningkatkan kesegaran jasmani siswa atau atlet untuk mengembangkan prestasi. Selain itu para Guru atu Pelatih akan membutuhkan sesuatu yang dinamakan demngan evaluasi. Yang bertujuan untuk mengoreksi dan mengetahui seberapa tingkat dan perkembangan setelah melakukan beberapa tahap latihan. Sebagai Pelatih dan Guru olahraga, yang bertanggung jawab atas prestasi anak asuhannya. Perlu melengkapi dirinya dengan pengetahuan tentang cara-cara mengukur dan menilai status kondisi fisik tersebut. Dan statrus kondisi fisik seseorang hanya mungkin diketahui dengan pengukuran dan penilaian yang berbentuk beberapa tes kemampuan.

Cara evaluasi yang tepat yang harus dilakukan yaitu dengan cara Tes dan Pengukuran terhadap atlet ataupun siswa. Tes dan pengukuran dapat dilakukan dengan beberapa cara dan tahap yang mempunyai manfaat dan tujan dilakukannya tes tersebut. Dan tes tersebut dibagi menjadi bebrapa komponen kondisi fisik serta beberapa jenis tes yan sudah dikelompokan. Dengan melakukan tes dan pengukuran ini kita dapat mengambil beberapa manfaat, diantaranya kita dapat mengevaluasi tahap latihan yang telah dilakukan, dengan hal itu kita dapat mengetahui seberapa perkembangan kondisi fisik seseorang, selain kita bisa mengembangkan prestasi atlet, kita juga bisa menjadikan ini sebagai bahan perbaikan dalam pemebelajaran atau pelatihan. 


\section{METODE}

Metode yang digunakan pada pelaksanaan kegiatan pengabdian kepada masyarakat ini menggunakan pendekatan Tes dan Pengukuran. Tim Universitas Bina Darma akan melaksanakan kegiatan selama 56 jam. Adapun tes dan pengukuran yang dilakukan meliputi:

1. Tes dan Pengukuran Antropometri

2. Tes dan Pengukuran Kecepatan (Speed)

3. Tes dan Pengukuran Kelincahan (Agelity)

4. Tes dan Pengukuran Kekuatan (Strange)

- Kekuatan Otot Lengan

- Kekuatan Otot Tungkai

5. Tes dan Pengukuran Power Otot Tungkai

6. Tes Daya Tahan (Endurance)

7. Tes Keterampilan Bola Tangan

\section{HASIL PEMBAHASAN, DAN DAMPAK}

Semula munculnya gagasan melaksanakan Tes dan Pengukuran kondisi fisik dan keterampilan berlandaskan pembangunan olahraga yang mengacu pada pembangunan olahraga untuk mewujudan perbaikan yang lebih baik menuju kehendak dari keinginan untuk membentuk manusia Indonesia seutuhnya berdasarkan Pancasila dan UndangUndang Dasar 1945. Pembangunan olahraga Bola Tangan adalah bagian integral dari pembangunan bangsa Indonesia dalam rangka mewujudkan cita-cita perjuangan rakyat dan Bangsa Indonesia, khususnya dalam mengharumkan nama bangsa dan negara melalui prestasi cabang olahraga Bola Tangan.

Menyadari akan pentingnya fungsi olahraga Bola Tangan dalam peranannya dalam pembangunan olahraga di Indonesia, maka dianggap perlu untuk menyesuaikan gerak langkah pelaksanaan pembangunan Bola Tangan Indonesia, melalui kegiatan kegiatan yang yang mengacu pada pembinaan prestasi yang lebih baik dalam langkah menuju prestasi yang gemilang khususnya di kota Palembang.

Maka dari itu Peserta yang mengikuti Tes dan Pengukuran kondisi fisik dan keterampilan baik itu Atletnya maupun Pelatihnya diharapkan nanti untuk kedepannya mempunyai bekal dan mampu berdedikasi untuk turut serta dalam memajukan kegiatan 
olahraga untuk dapat berprestasi di Kota Palembang khususnya dalam cabang Bola Tangan.

\section{SIMPULAN}

Terselenggaranya tes dan pengukuran kondisi fisik dan keterampilan dapat meningkatkan motivasi atlet dalam meningkatkan hasil latihannya yang nantinya dapat berimbas pada prestasi olahraga Bola Tangan.

Tes dan pengukuran kondisi fisik dan keterampilan ini mempunyai efektivitas dan efisiensi yang tinggi bagi Pelatih dalam menentukan tingkat kemampuan, mengelompokan sesuai kemampuan, mendiagnosa kelemahan, membebaskan dari program latihan tertentu, meramalkan kemampuan atlet mendatang, menyusun program latihan, mengevaluasi program dan pelaksanaan latihan serta merevisi program dan pelaksanaan latihan..

\section{DAFTAR PUSTAKA}

Harsono. 1988. Coaching dan Aspek Psikologi dalam Choaching. Jakarta: Departemen Pendidikan dan Kebudayaan, Direktorat Jenderal Pendidikan Tinggi, Proyek Pengembangan Lembaga Pendidikan Tenaga Kependidikan.

International Handball Federation, Rules Of The Game. Jakarta DIFAMATA Sport EO

Mahendra, Agus. 2000. Dasar-dasar Bola Tangan. Bandung: Depdiknas.

Nugraha, Adrian. 2010. Mengenal Aneka Cabang Olahraga. Bekasi: PT Cahaya Pustaka Raga.

Sajoto. 1995. Peningkatan dan Pembinaan Kekuatan Kondisi Fisik dalam Olahraga. Semarang: Dahara Prize.

Saputra, Yudha M. 2003. Pembelajaran Permainan Bola Tangan. Bandung: Departemen Pendidikan Nasional.

Soejono. 1983. Ilmu Coaching Umum, FKIK FPOK, Yogyakarta

Syafruddin. 2011. Ilmu Kepelatihan Olahraga. Padang: UNP Press.

Syarifuddin, Aip. 1991. Pengetahuan Olahraga. Jakarta : CV baru. 